\title{
Pola Lafal Bunyi Khusus Bahasa Jepang pada Tuturan Pembelajar Bahasa Jepang di Indonesia
}

\author{
Franky Reymond Najoan \\ Universitas Negeri Manado \\ frankynajoan@unima.ac.id
}

DOI: 10.18196/jjlel.3227

\begin{abstract}
Abstrak
Salah satu unsur bahasa Jepang yang cukup sulit pemerolehannya adalah bunyi khusus yang disebut special morae dan kaitannya dengan aksen. Penelitian terdahulu telah mencoba mengatasi masalah ini dengan berbagai cara, namun demikian, hasilnya belum memuaskan. Untuk itu penelitian ini hendak mencari tahu dan mengidentifikasi pola-pola ucapan pembelajar terlebih dahulu, sehingga dapat memberikan solusi pemecahannya. Penelitian dilakukan terhadap 13 orang mahasiswa. Mereka diminta mengucapkan daftar kosakata dan kalimat, dan ucapan mereka direkam, kemudian dianalisis menggunakan speech analyzer. Hasil pengolahan data menunjukkan bahwa dari 13 orang informan yang diminta untuk mengucapkan 13 kata stimulan yang diucapkan bersendiri dan yang dimasukkan dalam kalimat bingkai, rata-rata hanya 2 orang (15.4\%) yang pola ucapannya mendekati pola penutur asli. Adanya variasi pola ucapan yang cukup banyak menunjukkan bahwa pola lafal pembelajar berada dalam posisi bahasa antara dalam proses pemerolehan fonologi bahasa Jepang.
\end{abstract}

Kata Kunci: pola lafal; mora khusus; aksen; pemerolehan fonem

\begin{abstract}
One of the most difficult parts of Japanese language acquisition is a feature sound called special morae and its relation to accent. Previous researches have tried to overcome such a problem by using several methods, but the results have not been satisfactory yet. This research aims to identify pronunciation patterns used by the learners and find out the solutions to the problem. The researcher collected the data through an audio recording of 13 students who were to pronounce a list of words and sentences. Then, the data were analyzed using a speech analyzer. The results showed that out of 13 students pronouncing 13 stimuli words and 13 sentences that contained those stimuli words, only two students (15.4\%) could pronounce those words close to
\end{abstract}


native speaker-like. The variation of speech patterns indicates that the pronunciation pattern of the learners was in the inter-language position when acquiring the Japanese phonemes.

Keywords: pronunciation pattern; special mora; accent; phoneme acquisition

\section{Pendahuluan}

Ada beberapa unsur bunyi Bahasa Jepang yang menjadi kendala bagi pembelajar yang berlatar belakang bahasa ibu bahasa Indonesia untuk menguasai Bahasa Jepang secara cepat. Menurut hasil penelitian, unsur-unsur bunyi Bahasa Jepang yang merupakan masalah bagi pembelajar adalah aksen, intonasi, bunyi panjang, bunyi geminat dan lain-lain (Sukegawa 1992; Najoan 2008, 2002) . Di antara bunyi-bunyi ini ada beberapa bunyi yang dikategorikan sebagai bunyi khusus (special morae) yaitu, chouon (長音) atau bunyi panjang, sokuon (促音) atau bunyi geminat, dan hatsuon (撥音) atau bunyi nasal.

Bunyi khusus ini kemudian mendapat perhatian khusus karena dalam proses pemerolehan bahasa merupakan suatu kesulitan, khususnya bagi pembelajar yang bahasa ibunya tidak memiliki fitur bunyi seperti ini. Penyimpangan yang sering terjadi dalam kelas adalah terjadinya pemendekan durasi bunyi-bunyi yang seharusnya diucapkan panjang atau sebaliknya pemanjangan bunyi-bunyi yang seharusnya diucapkan pendek. Selain masalah durasi berkaitan juga dengan aksen. Misalnya, kata koukou (高校), pola aksennya adalah heiban (datar), tetapi sering kali terdengar ucapan pembelajar dengan pola atamadaka (suku awal tinggi).

Dalam proses pemerolehan bahasa Jepang untuk bunyi geminat dan bunyi vokal panjang ada beberapa pola yang dapat diidentifikasi yaitu: (a) pemendekan durasi konsonan yang seharusnya diucapkan panjang, (b) pemanjangan durasi secara berlebihan mengakibatkan terjadi pemanjangan vokal yang mengikutinya, (c) pola ucapan yang tidak konsisten, terutama pola aksen.

Penelitian ini berusaha mengidentifikasi pola-pola ucapan pembelajar mengenai bunyi-bunyi khusus bahasa Jepang. Dalam konteks bagaimana mereka 


\section{VOL. 3, NO. 2 AGUSTUS 2019

dapat melafalkan ketiga jenis bunyi khusus tersebut, bentuk-bentuk penyimpangan yang bagaimana, apakah penyimpangan itu terpola atau tidak? Jika terpola, pola-pola yang bagaimana?

Tujuan penelitian ini adalah untuk mengidentifikasi bentuk-bentuk penyimpangan lafal kata-kata yang mengandung bunyi khusus chouon (bunyi panjang), sokuon (geminat), dan hatsuon (nasal), khususnya tentang pola aksen kata-kata yang mengandung bunyi khusus tersebut oleh pembelajar bahasa Jepang pada program studi pendidikan bahasa Jepang. Selain itu, untuk mengetahui penyebab terjadinya penyimpangan tersebut perlu dikaji juga hubungannya dengan bahasa ibu pembelajar yaitu bahasa Indonesia.

Bahasa Jepang adalah bahasa yang menganut sistem suku kata terbuka yang terdiri dari Konsonan Vokal (KV). Suku kata ini disebut mora (モーラ) atau haku (拍). Sistem mora atau haku ini sangat penting dalam bahasa Jepang Biasanya satu suku kata mora atau haku ini dilambangkan dengan satu huruf Kana (Hiragana atau Katakana) yang merupakan paduan antara fonem konsonan dan vokal. Namun ada juga suku tertentu yang hanya terdiri dari satu fonem, sehingga dalam bahasa Jepang disebut bunyi khusus atau tokushuhaku (特殊拍) (The Japan Foundation, 2009).

Bunyi khusus bahasa Jepang adalah bunyi-bunyi yang secara fonologis memiliki beban fungsional, yaitu bunyi-bunyi seperti vokal panjang yang disebut chouon (長 音) yang secara fonemis dilambangkan dengan /R/ atau /H/, konsonan kembar atau geminat yang disebut sokuon (促音) yang secara fonemis dilambangkan dengan /Q/, dan bunyi sengau 「ん」yang disebut hatsuon (撥音), dilambangkan dengan /N/. Karna bentuknya seperti ini yang tidak terdiri dari Konsonan+Vokal sehingga disebut special morae, atau tokushuhaku (特殊拍) (The Japan Foundation, 2009).

Penelitian tentang bunyi khusus ini sudah banyak dilakukan, terutama yang berhubungan dengan pemerolehan bahasa. Toda (2003) mengatakan bahwa faktor- 
faktor yang mempengaruhi pemerolehan bahasa adalah faktor bahasa ibu dan faktor linguistis yang disebut markedness. Faktor linguistis berhubungan dengan sistem bahasa, yaitu ciri khas setiap bahasa. Mengenai pengaruh bahasa ibu, Toda menjelaskan bahwa bagi penutur asli bahasa Jepang, tokushuhaku adalah mora khusus yang berdiri sendiri yang dihargai sama kedudukannya dengan mora biasa. Misalnya kata “valentine” dalam bahasa Jepang disebut barentain (バレンタイン) yang terdiri dari 6 mora atau haku: /ba-re-n-ta-i-n/, padahal bahasa Inggrisnya hanya terdiri dari 3 suku/silabel saja: "va-len-tine". Jadi, dalam sistem suku kata, konsep mora dalam bahasa Jepang berbeda dengan sistem suku kata bahasa Inggris atau pun bahasa Indonesia yang menggunakan silabel sebagai satuan suku kata.

Bunyi khusus Bahasa Jepang tidak berdiri sendiri, karna terkait erat juga dengan aksen. Aksen bahasa Jepang terdiri dari 4 pola, yaitu atamadakagata 頭高型, nakadakagata 中高型, heibangata 平板型 dan odakagata 尾高型. Aksen bahasa Jepang adalah aksen nada, yaitu tinggi rendah dalam kata telah ditentukan, apabila nada telah turun tidak akan naik lagi. Untuk menggambarkan tinggi-rendahnya nada tersebut digunakan huruf H (high) untuk nada tinggi, dan L (low) untuk nada rendah.

Atamadakagata adalah aksen yang terletak di awal kata yaitu nada tinggi $(\mathrm{H})$ pada suku kata /mora pertama, dan mora selanjutnya adalah nada rendah (L). Misalnya kata : kirei terdiri dari 3 mora /ki-re-i/ yang nada tingginya terletak pada suku /ki-/ sehingga nadanya menjadi HLL. Nakadakagata adalah aksen yang nada tingginya terletak di tengah kata, tetapi letaknya berbeda-beda menurut jumlah mora dalam satu kata itu. Misalnya kata otousan terdiri dari 5 mora /o-to-u-sa-n/ dan nadanya tingginya terletak pada mora ke dua: LHLLL, tetapi kata koohii, nadanya tingginya terletak pada mora ke dua dan ke tiga sehingga menjadi LHHL. Heibangata adalah aksen datar, yaitu dari awal kata diucapkan dengan nada tinggi sampai akhir kata dan meskipun diikuti oleh partikel nadanya tetapi tinggi, sehingga disebut aksen datar. Misalnya, kata tomodachi menjadi LHHH. Sedangkan Odakagata adalah pola aksen akhir kata. Maksudnya nada tingginya sampai pada mora terakhir dan 


\section{VOL. 3, NO. 2 \\ AGUSTUS 2019 \\ 133}

langsung turun sesudah akhir kata. Hal ini akan tampak ketika diikuti partikel. Misalnya, kata musume ga menjadi HHHL, partikel "ga" nadanya rendah karena mengikuti nada kata.

Di lain pihak, aksen bahasa Indonesia, tidak banyak polanya. karena tidak memiliki beban fungsional. Menurut Halim, Aksen bahasa Indonesia sederhana saja, yaitu terletak di suku kata kedua dari belakang. Misalnya kata merdeka terdiri dari 3 suku/silabel: /mer-de-ka/, sehingga aksennya terletak pada suku kata /-de-/. Pola bahasa Indonesia ini kalau diterapkan ke dalam bahasa Jepang akan menyerupai aksen tengah atau nakadaka (中高).

Penelitian terdahulu yang berkaitan dengan bunyi khusus tersebut di atas, sudah cukup banyak. Namun dalam kajian pustaka di sini hanya dipilih yang terdekat dengan penelitian ini. Najoan (2008) mengadakan survei terhadap mahasiswa yang belajar bahasa Jepang, mendapati bahwa pelafalan bunyi khusus sebagai kesulitan bagi mahasiswa. Namun dalam penelitian ini tidak dikaji tentang pola lafal mereka. Tsurutani (2008) mengadakan penelitian terhadap pembelajar bahasa Jepang di Australia, mengenai bunyi panjang Bahasa Jepang. Trutani memperkirakan bahwa dalam ucapan pembelajar ada semacam pola, seperti misalnya kata "koukou" diucapkan [kooko] dengan aksen HHL. Dari hasil penelitiannya, ia mendapati penyimpangan pola ucapan pembelajar ternyata dipengaruhi oleh bahasa ibu. Najoan (2012) mengadakan penelitian khusus mengenai pelafalan bunyi panjang yang dihasilkan oleh pembelajar Indonesia, dan mendapati bahwa mereka tidak mengetahui adanya aksen dalam silabel bunyi panjang. Namun penelitian ini tidak diikuti dengan pengkajian tentang pola-pola aksen mereka.

Penelitian selama ini hanya difokuskan pada kesalahan berbahasa, kemudian dilanjutkan dengan pembelajaran untuk memperbaikinya. Kenyataan di lapangan, belum ditemukan bagaimana cara yang baik untuk memperbaiki kesalahan lafal 
pembelajar. Hal itu karena belum diketahui pola-pola atau bentuk kesalahan dari pembelajar. Oleh karena itu dalam penelitian ini perlu diadakan pengkajian tentang pola lafal para pembelajar, untuk mendapatkan gambaran pemerolehan lafal mereka.

\section{Metode Penelitian}

Penelitian ini menggunakan metode deskriptif. Data yang diperoleh dari informan kemudian dideskripsikan secara kualitatif, yaitu memaparkan pola-pola ujaran pada hasil tuturan informan. Dengan memaparkan pola-pola ujaran tersebut dapat diketahui bentuk-bentuk ujaran pada informan, apakah pola-pola itu berterima atau ada perbedaan dengan bahasa target.

Sumber data atau informan dalam penelitian ini adalah mahasiswa Universitas Negeri Manado Program Studi Pendidikan Bahasa Jepang semester 4 tahun ajaran 2015/2016 sebanyak 13 orang. Data dikumpulkan dengan teknik sadap, yaitu informan diminta untuk mengucapkan seperangkat instrumen penelitian berupa daftar kata dan kalimat. Kata-kata yang dipilih adalah kosakata yang mengandung bunyi khusus (/R/, /Q/, /N/) yang dimaksud dalam penelitian ini, dan merupakan kata-kata yang sudah dipelajari pada semester satu sampai empat, sehingga dianggap tidak mengalami kesulitan bagi pembelajar sebagai informan untuk mengucapkannya.

Data yang terkumpul mula-mula diedit dengan perangkat lunak pengolah bunyi/suara bernama Audacity (http://www. audacityteam. org/). Hasil rekaman diedit dengan cara memenggal bagian-bagian tuturan yang diperlukan untuk penelitian. Data berupa penggalan kata dan kalimat itu kemudian diolah dengan menggunakan perangkat lunak pengolah ujaran: Speech Analyzer (http://www01.sil.org/computing/sa/index.htm) untuk menampilkan hasil tuturan ke dalam bentuk spektogram (grafik bunyi yang memberikan informasi tentang perubahan dalam rentang waktu, frekuensi, dan intensitas gelombang bunyi 
menurut sumbu waktu), agar dapat melihat tinggi rendahnya suara, dan dapat mengukur durasinya. Setelah didapat hasil pengukuran tersebut kemudian datadata dikategorikan menurut bentuk-bentuk yang mirip sehingga didapatkan suatu pola.

\section{Hasil dan Pembahasan}

Hasil pengolahan data dipaparkan secara deskriptif seperti di bawah ini. Polapola aksen digambarkan dengan huruf "H" dan "L", ("H"=High 'tinggi', dan "L"=Low 'rendah'), sedangkan untuk durasi vokal, apabila terjadi pemendekan digambarkan dengan tanda titik (.), dan jika terjadi pemanjangan digambarkan dengan tanda garis datar (-) atau hyphen. Jika mora yang bersangkutan tidak terjadi pemanjangan maupun pemendekan maka tetap digambarkan dengan huruf $\mathrm{H}$ atau $\mathrm{L}$ sesuai nadanya.

\section{Pola lafal kata byouin「病院」}

Kata byouin (病院) terdiri dari 4 mora : 「びょ・う・い・ん」/byo-R-i-N/ dengan pola aksen datar HHHH atau heiban (平板). Dalam kata ini terdapat bunyi panjang /R/dalam silabel / byou-/ dan bunyi sengau /N/.

Hasil tuturan pembelajar, untuk kata byouin yang diucapkan secara bersendiri tidak ada satu pun yang sama dengan pola penutur aslinya. Seharusnya nada suara tidak pernah turun sampai akhir kata, tapi ada 10 orang $(76,9 \%)$ yang nadanya langsung turun pada mora ke dua: HLLL, dan tiga orang $(23,1 \%)$ lainya mengucapkan dengan nada turun pada mora terakhir: HHHL. Hal ini menunjukkan bahwa pola lafal kata byouin meski hanya 2 variasi tetapi tidak dapat mempertahankan aksennya. 
Hasil tuturan dalam kalimat bingkai (sentence frame) : "byouin wa doko desuka", ada 5 orang $(38,5 \%)$ yang melafalkan dengan benar, sedangkan sisanya sangat bervariasi. Ada 8 variasi pola yang menyimpang, yaitu: H.LL(L); HHHL(L); HHLL(H); LHHL(L); HHLL(L); LHLL (L); LHHH(H); LHHH(L), masing-masing 7,7\% atau setiap orang memiliki variasi sendiri. Hal ini menunjukkan kata byouin belum dikuasai dengan baik oleh pembelajar. Mereka hanya mengenal arti kata tetapi tidak mengetahui lafal yang sebenarnya.

\section{Pola lafal kata gakkou「学校」}

Kata gakkou (学校) ada 4 mora: が • つ・こ・う, /ga-Q-ko-R/ dengan pola aksen datar (HHHH) atau heiban 平板. Dalam kata ini terdapat dua mora khusus, geminat /Q/ dalam silabel /gak-/,dan bunyi panjang /R/ dalam /-kou/.

Hasil penuturan kata gakkou secara bersendiri hanya 2 orang $(15,4 \%)$ penutur yang pola lafalnya sama dengan pola penutur asli, sedangkan sisanya sangat bervariasi. Ada 8 variasi pola penyimpangan. Sedangkan hasil tuturan dalam kalimat bingkai: "gakkou wa itsu yasumi desuka" hanya3 orang (23\%) yang memiliki pola seperti penutur asli, sedangkan 10 orang lainnya memiliki pola masing-masing. Ada 9 variasi pola dari tuturan 10 orang tersebut. Ada 4 pola pelesapan vokal panjang yaitu: HHL.(H);H.LL(H); H.H.(L); HHH.(H) masing-masing 7\%. Variasi lainnya adalah: HHHH(l); HHHL(L); HHLL(H); HHLL(L) masing-masing 7\%; dan HHLL(L) 15.4\%; Meskipun kata ini sangat familier dengan pembelajar ternyata mereka memiliki pola masing-masing yang belum sesuai dengan pola penutur asli. Hal ini menunjukkan bahwa pembelajar belum mengetahui pola lafal yang benar dari kata gakkou meskipun kata ini memiliki frekuensi pemakaian yang tinggi.

\section{Pola lafal kata hikouki「飛行機」}

Kata hikouki (飛行機) terdiri dari 4 mora: ひ・こ・う・き/hi-ko-R-ki/ dengan pola aksen tengah tinggi (LHLL) atau nakadaka, 中高. Dalam kata ini terdapat mora khusus /R/ dalam silabel /-kou-/. 


\section{VOL. 3, NO. 2 AGUSTUS 2019}

Hasil penuturan kata hikouki ada 4 orang $(30,8 \%)$ yang melafalkan sesuai dengan pola penutur asli, sedangkan 7 orang lainnya $(53,8 \%)$ melafalkan dengan pola yang mirip, perbedaannya pada nada tingginya yaitu sampai pada mora ke 3 : LHHL, dan 2 orang lainnya: HHHL dan LHHH.

Selanjutnya ketika diucapkan dalam kalimat: "hikouki de ikimasu", hanya 3 orang $(23,1 \%)$ yang menuturkan sesuai dengan pola penutur asli, sedangkan sisanya dengan pola yang sangat bervariasi. Berbeda dengan tuturan kata per kata saja, pada tuturan kalimat ini, ada 7 variasi pola yang menyimpang yang teridentifikasi dalam tuturan informan, yaitu: HHHH(H) (23\%), LHHL(L) (23\%), dan LHHL(H), H-HHH(H), LHHH(H), LH.L(H) masing-masing (7,7\%). Hal ini menunjukkan bahwa baik tuturan kata bersendiri maupun dalam konteks kalimat, polanya sangat bervariasi, dan informan tidak dapat mempertahankan aksennya.

\section{Pola lafal kata issai 「一切」}

Kata issai (一切) ada 4 mora : • つ •さ・い/i-Q-sa-i/ dengan pola aksen mora awal tinggi (HLLL) atau atamadaka 頭高. Dalam kata ini terdapat satu mora khusus bunyi geminat /Q/ dalam silabel /is-/.

Hasil penuturan kata /issai/ menunjukkan hanya 1 orang $(7,7 \%)$ yang melafalkan sesuai dengan pola penutur asli. Sisanya tersebar pada 4 variasi pola, yaitu: HHHL (40,8\%), HHLL (46,2\%) , H.LL (7,7\%) terjadi pelesapan geminat, dan HHL (7\%) terjadi pemanjangan durasi vokal. Sedangkan hasil tuturan kata issai dalam kalimat ada 3 orang (23\%) yang polanya mendekati pola penutur asli, dan sisanya dengan sebaran 5 pola yang sangat bervariasi: HHHH(38\%); H.HH(15,4\%); HHHL; LHLL; LLHH (masing-masing 7,7\%). Hal ini menunjukkan kata issai belum dikuasai dengan baik oleh pembelajar dari segi lafal.

Pola lafal kata kaado 「カード」 
Kata kaado (カード) ada 3 mora: カ・ー・ド/ka-R-do/ dengan pola aksen suku awal tinggi (HLL) atau atamadaka 頭高. Dalam kata ini ada mora khusus /R/ dalam silabel / kaa-/.

Hasil penuturan kata kaado hanya 2 orang $(15,4 \%)$ saja yang lafalnya sesuai pola penutur asli. Sisanya hanya ada satu variasi penyimpangan, yaitu HHL $(84,6 \%)$. Sedangkan hasil tuturan dalam kalimat bingkai: "kaado o kudasai", menunjukkan hanya 1 orang $(7,7 \%)$ yang lafalnya mirip pola native speaker, sisanya ada 5 orang (38\%) dengan pola HHL(L), 4 orang (30,8\%) dengan pola HHH(L), dan 3 orang (23\%) dengan pola HHL(H).

\section{Pola lafal kata kitte「切手」}

Kata kitte (切手) terdiri dari 3 mora: き つ • て /ki-Q-te/ dengan pola aksen datar $(\mathrm{HHH})$ atau heiban 平板. Dalam kata ini ada satu mora khusus /Q/ dalam silabel / kit-/.

Hasil tuturan kata tersebut, hanya 3 orang (23\%) yang lafalnya sama dengan penutur asli, sisanya ada 3 variasi pola, di antaranya ada satu pola yang mengandung pelesapan geminat /Q/, sehingga ucapannya menjadi / kite/ (H.H), 6 orang (46,2\%) dengan pola HHL, 3 orang (23\%) dengan pola H-L (mora khusus geminat digantikan dengan bunyi panjang). Pelesapan dan substitusi mora khusus ini mengakibatkan perubahan bentuk kata dan perubahan makna. Sedangkan hasil penuturan /kitte/ dalam kalimat menunjukkan, hanya 3 orang $(23,1 \%)$ yang lafalnya sesuai dengan penutur asli. Sisanya bervariasi dalam empat pola: HHL(L) $(38,55), \operatorname{HHL}(\mathrm{H})(23 \%)$, HHH(L) (7,7\%), dan ada yang mengalami pelesapan mora khusus /Q/, yang mengakibatkan terjadi perubahan bentuk kata menjadi /kite/: H.L(L) $(7,7 \%)$.

\section{Pola lafal kata koohii,「コーヒー」}




\section{VOL. 3, NO. 2 AGUSTUS 2019

Kata koohii (コーヒー) ada 4 mora: コ・ー・ヒ・ー /ko-R-hi-R/ dengan pola aksen tengah tinggi (LHHL) atau nakadaka 中高. Dalam kata ini terdapat dua mora khusus /R/ yaitu di dalam silabel / kou-/ dan silabel /-hii/.

Hasil penuturan menunjukkan hanya 2 orang $(15,4 \%)$ saja yang melafalkan sesuai dengan pola penutur asli. Sisanya ada 3 variasi pola, satu dengan pola yang mirip (HHLL) diucapkan oleh sebagian besar informan $(69,2 \%)$ dan 2 pola lainnya mengandung pelesapan vokal akhir yang adalah mora khusus /R/. Selanjutnya hasil penuturan dalam kalimat bingkai: "watashi wa koohii ga nomenai" menunjukkan ada 3 orang (23\%) yang lafalnya sesuai dengan pola penutur asli, sedangkan 10 orang lainnya masing-masing dengan pola sebagai berikut: $\mathrm{HHHH}(\mathrm{H})(30,8 \%)$, HHLL (H)(15,4\%); dan HHL.(L); H.H. (H); L.HL (L); H.LL(H); masing-masing 7,7\%. Bahkan di dalamnya ada pelesapan vokal pada mora ke dua dan mora terakhir, maupun kedua-duanya. Akibatnya terjadilah perubahan bentuk kata menjadi: kohii ga; koohi ga; dan kohi ga. Sehingga kata koohii merupakan kata yang paling sulit lafalnya.

\section{Pola lafal kata minna「皆」}

Kata minna (皆) terdiri dari 3 mora: み・ん・な/mi-N-na/ dengan pola aksen datar $(\mathrm{HHH})$ atau heiban 平板、 terdapat mora khusus bunyi sengau /N/. Hasil penuturan kata minna, ada 4 orang $(30,8 \%)$ yang melafalkan sesuai dengan pola penutur asli. Sisanya hanya ada satu pola yang berbeda yaitu nada turun pada mora terakhir HHL $(61,5 \%)$ dan 1 orang melakukan pemanjangan durasi vokal pada akhir kata: HHL- (7,7\%). Sedangkan tuturan dalam kalimat: "Minna de ikimashou", menunjukkan bahwa hanya ada satu pola yang sesuai dengan pola penutur asli. Sedangkan 12 orang lainnya polanya sangat bervariasi: $\mathrm{HHH}(\mathrm{H})$ (46\%), HHL(L) $(15,4 \%), \operatorname{HHL}(\mathrm{H})(7,7 \%)$, dan ada yang terjadi pelesapan bunyi nasal /N/, sehingga menjadi mina: L.H(L), H.H(H), H.H(L) masing-masing 7,7\%. 


\section{Pola lafal kata tanjoubi「誕生日」}

Kata tanjoubi (誕生日) terdiri dari 5 mora: た・ん・じょ・う・び/ta-N-jo-Rbi/ dengan pola aksen datar (HHHHH) atau heiban 平板. Dalam kata ini terdapat 2 mora khusus yaitu bunyi sengau /N/dalam silabel /tan-/ dan bunyi panjang /R/ dalam silabel /-jou-/.

Hasil penuturan kata tersebut ada 2 orang $(15,4 \%)$ yang sesuai dengan pola penutur asli. Selain itu, polanya sangat bervariasi: HHHHL (30,8\%), LLHHL (23\%), LHH/L (7,7\%), LHHHL (7,7\%); HHHLL (7,7\%), HHHHL (7,7\%), HHHHH (7,7\%). Begitu juga penuturan kata tanjoubi dalam kalimat, menunjukkan bahwa hanya ada satu orang $(7,7 \%)$ yang mengucapkan sesuai dengan pola penutur asli. Sisanya sangat bervariasi. Setiap orang mempunyai ciri pola sendiri-sendiri: LHHHHH(H); dan LLLHLL(H) masing-masing 15,4\%; HHHHHH(H); LHHH/L (L); LHHH/H; LLLHHL (L); HHHHHL(H); LHHHHL(L); LLLHHL(H); LHLLLL(L) masing-masing 7,7\%. Hal ini menunjukkan bahwa pembelajar menghafal kata ini tidak dengan aksen dan tidak memperhatikan mora khusus.

\section{Pola lafal kata raishuu 「来週」}

Kata raishuu (来週) terdiri dari 4 mora: ら・い・し中・う/ra-i-shu-R/ dengan pola aksen datar $(\mathrm{HHH})$ atau heiban 平板. Dalam kata ini terdapat mora khusus /R/ dalam silabel /-shuu/.

Hasil penuturan kata tersebut hanya ada satu orang $(7,7 \%)$ yang polanya sesuai dengan pola penutur asli sedangkan sisanya tersebar dalam 2 pola yang berbeda: HHLL (46,2\%), dan HHHL (38,5\%). Tetapi, hasil penuturan dalam kalimat bingkai: "raishuu shiken desu" menunjukkan bahwa ada 8 orang $(61,5 \%)$ dengan pola HHHH(H), dan sisanya 3 orang (23\%) dengan pola HHLL(H), pola HHHL(L) 1 orang $(7,7 \%)$ dan 1 orang $(7,7 \%)$ mengalami pelesapan LHH.(L). 


\section{VOL. 3, NO. 2 AGUSTUS 2019

\section{Pola lafal kata sensei「先生」}

Kata sensei (先生) terdiri dari 4 mora: せ • ん • せ ・ い/se-N-se-R/dengan pola aksen tengah (LHHL) atau nakadaka 中高型. Dalam kata ini terdapat mora khusus /N/ dalam silabel /sen-/ dan /R/ dalam silabel /-see/

Hasil penuturan kata menunjukkan bahwa ada 4 orang $(30,8 \%)$ yang polanya sesuai dengan pola penutur asli. Sisanya ada dua pola: 8 orang $(61,5 \%)$ dengan pola HHLL dan 1 orang $(7,7 \%)$ dengan pola HHH. Sedangkan hasil tuturan dalam kalimat bingkai: “watashi wa sensei ni naritai desu” menunjukkan bahwa ada 5 orang $(38,5 \%)$ yang polanya sesuai dengan pola penutur asli, dan sisanya tersebar ke lima pola yang berbeda: HHLL (23\%); LLLL(H) (15,4\%); dan LHLL; HLLL(L); HHHL (L)masingmasing 7,7\%. Ini menunjukkan masih banyak informan yang belum menguasai pola ucapan kata /sensei/ padahal kata ini merupakan kata yang frekuensi pemakaiannya cukup tinggi dalam kehidupan di lingkungan belajar.

\section{Pola lafal kata suupaa 「スーパー」}

Kata suupaa (スーパー) terdiri dari 4 mora: ス・ー・パ・ー /su-R-pa-R/ dengan pola aksen awal (HLLL) atau atamadaka, 頭高. Dalam kata ini terdapat mora khusus /R/ pada awal kata /suu-/ dan pada akhir kata /-paa/.

Hasil penuturan kata menunjukkan hanya 1 orang yang polanya sesuai dengan pola penutur asli. Sisanya ada 5 pola yang berbeda (HHLL $(53,8 \%)$; LHL. $(15,4 \%)$; H.L. (7,7\%); L.HH (7,7\%); dan HHHH (7,7\%) dan di dalamnya banyak terdapat pemendekan durasi vokal baik pada awal kata maupun pada akhir kata. Bahkan hasil penuturan dalam kalimat bingkai: "suupaa de kaimashita" menunjukkan bahwa tidak ada seorang pun yang polanya sesuai dengan penutur asli. Pola-polanya adalah: HHHH(30,8\%) Yang lain HHLL (53,8\%);H.LL(15,4\%); HHLL (15,4\%); HH.L. (7\%); dan LHH(7,7\%), namun penyimpangannya adalah terjadi pemendekan durasi vokal. 


\section{Pola lafal kata techou「手帳」}

Kata techou (手帳) terdiri dari 3 mora:て・ちょ・う/te-cho-R/ dengan pola aksen datar (LHH) atau heiban 平板. Dalam kata ini terdapat mora khusus /R/ pada akhir kata /-chou/.

Hasil penuturan kata menunjukkan hanya ada 2 orang (15.4\%) yang polanya sesuai dengan pola penutur asli. Sisanya bervariasi dalam 4 jenis pola: HLL $(46,2 \%)$; HHL (15,4\%); H-LL (15,4\%); HHL(7,7\%). Tetapi, hasil penuturan dalam kalimat bingkai: "kore wa watashi no techoudesu, menunjukkan ada 3 orang $(23,1 \%)$ yang lafalnya sesuai dengan lafal penutur asli. Pola informan tersebar ke dalam 4 jenis pola yang semuanya diawali dengan nada tinggi (HL(L) (23\%); HLL(L) (46\%); HHL(L) $(7,7 \%)$.

Setelah dipaparkan hasil tuturan setiap kata, baik yang diucapkan bersendiri maupun yang dimasukkan dalam kalimat bingkai, berikut ini akan ditampilkan hasil keseluruhan yang direkapitulasi dalam Tabel $1 \mathrm{di}$ bawah ini.

Seperti tampak pada tabel 1, angka jumlah benar menunjukkan berapa banyak pembelajar yang dapat mengucapkan dengan benar setiap kata tersebut, sedangkan jumlah variasi pola menunjukkan bahwa selain ucapan yang benar ada berapa banyak pola ucapan yang tidak sesuai dengan penutur asli.

Tabel 1 Rekapitulasi Hasil Tuturan Pembelajar 
VOL. 3, NO. 2

AGUSTUS 2019

143

\begin{tabular}{|c|c|c|c|c|c|}
\hline No. & Kata (aksen) & Mora & $\begin{array}{l}\text { Jumlah } \\
\text { benar }\end{array}$ & $\%$ & $\begin{array}{c}\text { Jumlah variasi } \\
\text { pola }\end{array}$ \\
\hline 1 & びょういん (HHHH) & /byo-u-in/ & 0 & 0.0 & 2 \\
\hline 2 & びょういんは & /byo-R-i-N/ wa & 5 & 38.5 & 8 \\
\hline 3 & がっこう (HHHH) & /ga-Q-ko-R/ & 2 & 15.4 & 7 \\
\hline 4 & がっこうは & /ga-Q-ko-R / wa & 3 & 23.1 & 10 \\
\hline 5 & ひこうき (LHLL) & /hi-ko-R-ki/ & 4 & 30.8 & 3 \\
\hline 6 & ひこうきで & /hi-ko-R-ki/ de & 3 & 23.1 & 7 \\
\hline 7 & いっさい (HLLL) & /i-Q-sa-i/ & 1 & 7.7 & 4 \\
\hline 8 & いっさい関係ない & /i-Q-sa-i/ _ ...nai & 3 & 23.1 & 5 \\
\hline 9 & カード (HLL) & /ka-R-do/ & 2 & 15.4 & 1 \\
\hline 10 & カードをください & /ka-R-do/o & 1 & 7.7 & 3 \\
\hline 11 & きって (HHH) & /ki-Q-te/ & 3 & 23.1 & 3 \\
\hline 12 & きってをください & /ki-Q-te/ o & 3 & 23.1 & 4 \\
\hline 13 & コーヒー (LHHL) & /ko-R-hi-R/ & 2 & 15.4 & 3 \\
\hline 14 & コーヒーが & /ko-R-hi-R/ & 0 & 0.0 & 6 \\
\hline 15 & みんな (HHH) & /mi-N-na/ & 4 & 30.8 & 5 \\
\hline 16 & みんなで & /mi-N-na/ de & 0 & 0.0 & 6 \\
\hline 17 & たんじょうび (LHHLL) & /ta-N-jo-R-bi/ & 0 & 0.0 & 6 \\
\hline 18 & おたんじょうびは & /o-ta-N-jo-R-bi/wa & 1 & 7.7 & 10 \\
\hline 19 & らいしゅう (LHHH) & /ra-i-shu-R/ & 1 & 7.7 & 3 \\
\hline 20 & らいしゅう試験 & /ra-i-shu-R / & 1 & 7.7 & 4 \\
\hline 21 & せんせい (LHHL) & /se-N-se-R/ & 4 & 30.8 & 1 \\
\hline 22 & せんせいに & /se-N-se-R/ ini & 3 & 23.1 & 5 \\
\hline 23 & スーパー (HLLL) & /su-R-pa-R/ & 1 & 7.7 & 5 \\
\hline 24 & スーパーで & /su-R-pa-R/ de & 0 & 0.0 & 4 \\
\hline 25 & てちょう (LHH) & /te-cho-R/ & 2 & 15.4 & 4 \\
\hline \multirow[t]{2}{*}{26} & てちょうです & /te-ch-o-R/ desu & 3 & 23.1 & 3 \\
\hline & & Jumalah Rata-rata & 2 & 15.4 & \\
\hline
\end{tabular}

Mencermati hasil pengolahan data di atas, tampak jelas bahwa kata-kata yang diucapkan bersendiri dan yang dimasukkan dalam kalimat, rata-rata hanya 2 orang $(15,4 \%)$ yang dapat mengucapkan dengan baik sesuai pola penutur asli. Ternyata lafal pembelajar bervariasi pada setiap kata. Hal ini menunjukkan bahwa informan yang adalah pembelajar bidang Bahasa Jepang belum dapat melafalkan dengan baik kata-kata yang dijadikan instrumen penelitian. Kata-kata yang dipilih merupakan kata-kata yang sudah dikenal oleh para informan karena mereka telah belajar sejak 


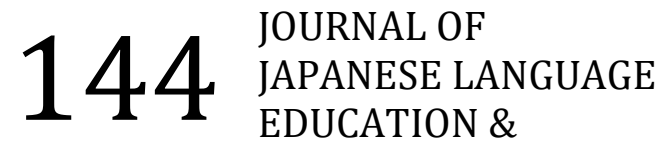 \\ LINGUISTICS}

semester satu, sampai pada saat data diambil mereka telah menjalani 4 semester. Lalu mengapa mereka tidak dapat menyerap dengan baik lafal bahasa Jepang yang seharusnya? Apakah lafal bahasa Jepang itu susah? Bagaimana perbedaannya dengan bahasa Indonesia?

Jika melihat pola-pola ucapan informan, ada pola-pola yang merupakan pengaruh bahasa Ibu pembelajar (bahasa Indonesia). Salah satu pengaruh bahasa Indonesia adalah sistim suku kata. Suku kata bahasa Indonesia adalah sistem silabel, sedangkan bahasa Jepang sistem mora. Perbedaan ini mempengaruhi pembelajar ketika berhadapan dengan pola aksen bahasa Jepang. Khususnya untuk ketiga bunyi /R/, /Q/, /N/ ini mudah terjadi hal tersebut karena mudah terseret ke sistem silabel. Misalnya pada kata gakkou, meskipun terdiri dari 4 mora: が • •こ・う/ga-Qko-R/, tetapi dalam tuturan cenderung lebih mudah menjadi 2 silabel : がっ・こう /gaQ-koR/. Akibat perubahan struktur ini, maka aksen juga mengikuti pola ini. Aksen bahasa Indonesia ialah, puncak nada terjadi pada silabel ke dua dari belakang, misalnya kata: makmur terdiri dari silabel /mak-mur/, sehingga aksennya terletak pada suku kata /mak-/ yang mirip dengan pola Jepang atamadakagata (HL). Pola ini kemudian terbawa ke kata gakkou sehingga bukan saja mengubah aksen, tetapi juga mengubah kuantitas (durasi) bunyi. Karena dalam bahasa Indonesia tidak dikenal adanya bunyi panjang, sehingga pengucapan satu suku kata silabel sangat mana suka sekalipun dalam silabel itu terdapat dua vokal berurutan.

Lalu bagaimana dengan kata-kata yang pola aksennya tidak mengikuti pola bahasa ibu? Seperti tampak pada tabel 1 di atas, setiap kata ada variasi pola. Variasi pola lafal yang begitu banyak dan tidak konsisten karena tidak menunjukkan satu pola yang tetap. Inilah yang disebut bahasa antara (interlanguage). Biasanya terjadi ketika pembelajar mengenal bahasa target tetapi belum sepenuhnya menyerap bahasa target. Dengan demikian, lafal pembelajar pada saat pengambilan data berada pada lafal bahasa antara yang merupakan ciri khas pembelajar. Gejala ini ternyata tidak hanya terdapat pada pembelajar yang berlatar belakang bahasa ibu 


\section{VOL. 3, NO. 2 AGUSTUS 2019

bahasa Indonesia saja, sebab penelitian Toda (2003) yang mengambil sampel pembelajar berlatar belakang bahasa Inggris pun menunjukkan gejala yang sama, sehingga gejala ini dapat dikatakan sebagai gejala universal.

\section{Kesimpulan}

Setelah mengikuti analisis data dan pembahasan di atas, maka dapat ditarik kesimpulan sebagai berikut:

- Ternyata pembelajar tidak memiliki pola tertentu terhadap lafal bunyi khusus. Masing-masing mempunyai polanya sendiri dan bersifat inkonsisten. Banyaknya variasi pola lafal menunjukkan bahwa bunyi khusus /R/, /Q/, /N/ bahasa Jepang merupakan yang paling sulit dalam pemerolehan bahasa Jepang.

- Pembelajar yang berlatar belakang bahasa Indonesia mengalami kesulitan untuk menyerap pola lafal ini karena secara linguistis bunyi khusus bukan hanya soal durasi tetapi juga berhubungan erat dengan aksen, dan faktor bahasa Ibu juga turut berpengaruh.

- Sebagian besar informan belum menyerap pola aksen kata-kata yang mengandung ketiga bunyi khusus /R/, /Q/ dan /N/. Variasi pola aksen yang cukup banyak menunjukkan pembelajar berada dalam posisi bahasa antara dalam proses pemerolehan bahasa Jepang.

Penelitian kali ini hanya difokuskan pada pola aksen dari kata-kata yang mengandung ketiga bunyi khusus /R/, /Q/ dan /N/. Selanjutnya perlu dikaji lagi hubungan antara aksen dan durasi ucapan bunyi-bunyi khusus tersebut.

Setelah mengetahui pola-pola lafal pembelajar tersebut, maka perlu ditindaklanjuti dengan percobaan pembelajaran, memilih metode yang cocok untuk memperbaiki penyimpangan lafal tersebut dan metode pembelajaran untuk memberikan pemerolehan yang benar sejak dini. 


\section{Referensi}

Halim, A. (1984). Intonasi, dalam hubungan dengan sintaksis bahasa indonesia. Jakarta: Djambatan

Najoan, F.R.(2008). Indonesia nihongo gakushuusha ni yoru nihongo no hatsuon chosa. Jurnal Interlingua FBS Unima Vol. 1

Najoan, F.R. et.al.(2012). The acquisition of japanese vowel length contrast by indonesian native speakers: Evidence from perception and production. Journal of Fonetik Society of Japan, Vol.16 No.2, Agust, 2012pp.28 - 39

Toda, T.(2003) Second language speech perception and production: Acquisition of phonological contrasts in japanese. Lanham, MD: University Press of America.

Toda, T. (2003). Acquisition of special morae in japanese as a second language [in Japanese].Journal of the Phonetic Society of Japan 7(2), 70-83

The Japan Foundation. (2009). Onsei o oshieru. Tokyo: Hitsuji shobo

Tsurutani, C.(2008). Pronunciation and rhythm of japanese as a second language. Hiroshima: Keisui.

Catatan:

Penelitian ini terlaksana atas bantuan dana PNBP Universitas Negeri Manado tahun 2018. Untuk itu disampaikan terima kasih kepada Rektor Unima dan Ketua LPPM yang telah memungkinkan penelitian ini terlaksana.

Sebagian hasil penelitian ini telah dipresentasikan dalam Simposium Internasional di Universitas Hanoi, Vietnam pada tanggal 17 Oktober 2018, dalam Bahasa Jepang. 